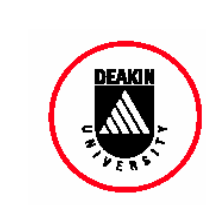

Faculty of Business and Law

SCHOOL OF ACCOUNTING, ECONOMICS AND FINANCE

School Working Paper - Economic Series 2007

SWP 2007/01

\title{
UNIONS AND PROFITABILITY: A META-ANALYSIS
}

\section{HRISTOS DOUCOULIAGOS AND PATRICE LAROCHE}

The working papers are a series of manuscripts in their draft form. Please do not quote without obtaining the author's consent as these works are in their draft form. The views expressed in this paper are those of the author and not necessarily endorsed by the School. 


\section{UNIONS AND PROFITABILITY: A META-ANALYSIS}

HRISTOS DOUCOULIAGOS AND PATRICE LAROCHE

Doucouliagos: School of Accounting, Economics and Finance, Deakin University, 221 Burwood Highway, Burwood, 3125, Victoria, Australia.

Email: douc@deakin.edu.au. Phone: 610392446531

Laroche: Institut Universitaire de Technologie, University of Nancy 2, 2 ter boulevard Charlemagne 54052 Nancy Cedex - France.

Email: patrice.laroche@univ-nancy2.fr Phone: +33 3839132 21. Fax. +33 383913183 


\title{
UNIONS AND PROFITABILITY: A META-ANALYSIS
}

\begin{abstract}
The effect of unions on profits continues to be an unresolved empirical issue. In this paper, meta-regression analysis is applied to the population of 45 econometric studies that report 532 estimates of the direct effect of unions on profits. We show that unions have a significant negative effect on profits, and that this effect is larger in the US. Separate meta-regression analysis is used to identify the sources of union-profit effects. Meta-analysis of 239 estimates of unions interacted with the hypothesized sources of union rents reveals that neither the market power nor the quasi-rent appropriation theories are supported by the extant studies. Analysis of the between-study heterogeneity reveals that unions have an indirect effect on factor accumulation - they depress physical capital formation and stimulate advertising expenditure. There is a clear need for additional primary research in this area.
\end{abstract}




\section{UNIONS AND PROFITABILITY: A META-ANALYSIS}

\section{Introduction}

Interest in the impact of unions on economic performance has motivated a considerable body of research examining the impact of unions on productivity and financial performance (see Metcalf 2003 and Turnbull 2003, for recent reviews). The broad view emerging from this literature is that the impact of unions on profitability is a priori indeterminate, as any positive union effect on productivity may be offset by rising labor costs. With respect to the latter, (Hirsch 1991, p. 36) notes that: "there is disagreement as to the magnitude of the profit reduction and the sources from which union gains obtain"1

The disagreement Hirsch refers to may arise because empirical estimates of the impact of unionism on profitability differ depending on the measure of profitability, the country examined, the estimation technique used and the measure of unionization (Karahasan 1995). These may all affect reported estimates. Additionally, there is the ever present issue of sampling error which has long been known to result in the appearance of divergent results (see Hunter and Schmidt 2004 for an excellent and extended discussion on this issue). While many studies find a statistically significant negative union-profit effect, Menezes-Filho (1997) suggests that the negative effect of unions on profits has reduced dramatically during the 1980s and the 1990s, and is now insignificant. Batt and Welbourne (2002, p. 169) confirm Menezes-Filho's findings by showing that: "unionization does not inevitably reduce financial performance". Their empirical results show that unions are associated with superior financial performance in entrepreneurial firms. More recently, Guest et al. (2003) and Laroche (2004) report positive but statistically insignificant union-profitability effects, while Gittell et al. (2004) found a positive and statistically significant effect.

This paper is the first to offer a research synthesis of the available empirical literature through the application of meta-analysis. Meta-analysis is a set of statistical techniques that has been developed to identify and quantify associations drawn from an existing body of literature (see Wolf 1986; Hunter and Schmidt 1990; and Stanley 2001). Meta-analysis enables a literature to be assessed with a wider set of tools than is available in a traditional qualitative literature review. The aims of our meta-analysis are to: (1) provide a statistical integration of the existing research on the relationship between unions and firm financial performance; (2) assess the competing claims made about the impact of unions on profits; (3) identify the source of union-profit effects; and (4) explore the differences in reported union- 
profit effects between studies. In order to do this, we apply meta-analysis to four separate though related empirical literatures: (a) the union-profit effects literature; (b) the impact of market power on profits literature; (c) the impact of tangible and intangible investments on profits literature; and (d) the literature on the interactions between unions and market power and unions and investments literatures. Through meta-regression analysis of these literatures we are able to show that several robust conclusions emerge.

The next section discusses the theory of union-profit effects. This is followed by a discussion on the data used in section 3 and presentation of the analytical framework in section 4. Meta-regression analysis is used to explore union-profit effects in section 5, while the sources of these effects are investigated in section 6 . The between-study heterogeneity is explored in section 7. Section 8 concludes the paper.

\section{Theoretical Background}

Neoclassical labor economics theory postulates that there is a negative relationship between unions and corporate financial performance, arising from unions' ability to extract rents in the form of higher wages (Booth 1995). One of the most well established empirical effects of unions is their ability to increase wages above competitive levels (Lewis 1963 and Jarrell and Stanley 1990). Higher wages reduce profits unless union activities can offset higher labor costs through, for example, higher productivity or by passing the higher costs on to consumers (Hirsch 1991). A union's impact on financial performance depends on the scale of potential rents, which is related to both the market structure facing the firm, and also on the bargaining power of unions. Firms with a competitive advantage or those operating in less competitive markets have greater opportunities to earn monopoly profits. In such cases, unions find it relatively easier to extract higher wages for their members and workers in general (Hirsch and Addison 1986). Similarly, by using their bargaining power and, in particular, their ability to mobilize workers on wage grievances, unions are able to affect wage levels.

This economic approach is based on the idea that the relationship between unions and employers is "a zero-sum game", in which the gains obtained by one party are the exact compensation of losses supported by the other party (Walton and MacKersie 1965). An alternative theory argues that union presence can have a positive effect on productivity and this effect would balance the negative impact of unions on wages. This conceptual framework is the so-called 'two faces' view of unionism (Freeman and Medoff 1984): the monopoly face and the collective voice/institutional response face. By providing workers with a means of 
expressing discontent at the workplace, unions can reduce the extent to which quits and absenteeism lead to a sub-optimal degree of labor turnover. Unions are thus an alternative to resignation and apathy. By giving a voice to unsatisfied workers, unions can improve worker's motivation and, therefore, improve labor productivity (Freeman and Medoff, 1984). Thus, this higher level of labor productivity can offset union rents obtained through collective bargaining.

On the other hand, there are solid theoretical arguments to suggest that unions may reduce productivity, through for example featherbedding, inflexible working arrangements and industrial disputation (see Hirsch and Addison 1986 and Hirsch 1991b). Additionally, evidence suggests that unions may have a detrimental impact on total factor productivity growth.

It is theoretically difficult to predict the impact of unions on firm financial performance, hence the need for empirical analysis. The meta-analysis study by Jarrell and Stanley (1990) established a clear negative impact on labor costs (unions increase wages), while the meta-analysis by Doucouliagos and Laroche (2003b) established a clear negative impact on total factor productivity. These adverse effects are not outweighted by the near zero impact of unions on productivity levels (Doucouliagos and Laroche, 2003a). In their meta-analysis, Doucouliagos and Laroche (2003a, p.682) conclude that: "if all of the available evidence is pooled together, measures of central tendency indicate a near zero association between unions and productivity. However, there exist country and industry specific associations between unions and productivity". This suggests that significant net productivity improvements are not forthcoming to compensate a unionized firm/industry for higher labor costs. Taken together, these three meta-analyses imply indirectly a negative union-profit effect. This is confirmed by the direct meta-analysis of the union-profit effects literature presented in this paper.

Meta-analysis can be used to test hypotheses by pooling the results from all studies, in a similar fashion to the way that individual studies are used to test and explore hypotheses. In this paper we use meta-analysis to explore three issues: (I1) Do unions have an overall negative impact on profits? (I2) Does the source of the union-profit effect derive from market power or the appropriation of rents from long lived capital and intangible assets? (I3) What factors explain the heterogeneity in the observed union-profit effects. 


\section{Data}

Meta-analysis should be based on the population of studies or at least a random sample from the population of studies. In order to construct a comprehensive datase, a series of computer searches was conducted on the Proquest/ABI Inform, EBSCO and EconLit databases, using keyword searches such as 'unions and performance', 'unions and profitability', 'unions and profits', and 'industrial relations and profitability'. Additionally, extensive manual searches were also performed to identify additional articles, using the reference lists of each study collected. These searches yielded a total of 87 published empirical studies that reported test statistics on the impact of unions and financial performance.

To be included in the meta-analysis, a study was required to examine financial performance as the dependent variable. Several measures of financial performance are used in the literature, including return on capital, return on investment, return on assets, Tobin's q, price cost margin, profit to sales ratio and excess value. In the subsequent meta-regression analysis (MRA) we test whether the definition of the dependent variable influences the estimated union-profit effect.

Studies included in the meta-analysis had to report also information on sample size and a regression coefficient or another statistic which could be converted to partial correlations, such as standard errors or t-statistics. Following Doucouliagos (1995), Djankov and Murrell (2002) and Doucouliagos and Laroche (2003a), the partial correlation was chosen as a measure of the union-profits effect, as many studies do not offer sufficient information from which to calculate accurately the percentage impact of unions on profits. That is, even though the primary interest in this literature is on the impact of unions on profitability, many studies do not report (or provide enough information from which to calculate) the percentage reduction/increase in profitability attributable to unions. The partial correlation is a standardized measure of the degree of association between unions and profits, controlling for the influence of other factors. The use of partial correlations is particularly important in our case, as we present meta-analysis for several literatures: union-profit effects; market power-profit effects; tangible and intangible investment-profit effects; union and market power interaction profit effects; and union and investment interaction profit effects. The partial correlation enables comparisons to be made across these diverse literatures.

Close examination resulted in several studies been excluded from the meta-analysis because of methodological reasons. Excluded were studies that did not report any statistical information from which effect sizes could be determined and studies that did not provide all the necessary data. ${ }^{2}$ In cases where studies use the same data and are conducted by the same 
author(s), we use the average of these. We excluded also event studies as these are also not comparable. Hence, we do not include the studies by authors such as Ruback and Zimmerman (1984) and Becker and Olson (1989).

Studies that explore the impact of unions on financial performance can be divided into two categories. First, there is the group of studies that explores the impact of unions on profitability within a multivariate framework typically using OLS. This is the largest group of studies (45 studies using a total sample size of 89,650). These 45 studies offer 532 estimates of union-financial performance effects. Second, there is a relatively smaller group that also uses a multivariate framework but uses probit analysis (20 studies with a total sample size of 1,550). Even though both groups of studies inform on the direction of the association between unions and profits, they are not strictly comparable. ${ }^{3}$ More importantly, the probit studies all use subjective financial performance data, while the other 45 studies use objective measures of performance. Hence, for reasons of comparability, we chose to exclude probit studies from our meta-analysis. The list of the 45 studies included in the meta-analysis is presented in the reference section of this paper. The earliest included study was published in 1975. Hence, we are covering a literature that has now spanned three decades.

\section{Analytical Framework}

The starting point in meta-analysis to quantifying an empirical association is the calculation of average effect sizes and the construction of confidence intervals around these. The most widely used estimate of the 'true' effect, $\eta$, is a simple weighted mean:

$$
\hat{\eta}_{w}=\sum N_{i} \hat{\eta}_{i} / \sum N_{i}
$$

where $\hat{\eta}_{i}$ is the reported union-profit effect and $N_{i}$ is sample size associated with the $\mathrm{i}^{\text {th }}$ study. This weighted effect will be an unbiased estimate of the population effect, as long as the studies included in the calculation of equation (1) are all the available estimates, or a random sample from the population of all estimates (see Hunter and Schmidt 2004). For the union-profit effects literature, the mean partial correlation is -0.09 and the median is -0.08 . The weighted average partial correlation using sample size as the weights is -0.07 . The 95 percent confidence interval around the weighted average partial correlation is -0.09 to -0.06 . ${ }^{4}$ Thus, meta-analysis confirms what has been concluded from traditional qualitative literature 
reviews: Taking all the accumulated evidence over the past thirty years, meta-analysis reveals that, on average, unions have a significant negative effect on profits.

\subsection{Meta-Significance Tests (MST)}

Unfortunately, averages and confidence intervals can be distorted if the literature is affected adversely by publication selection effects. Selection occurs when studies are accepted for publication on the basis of the statistical significance of results, and/or on whether the results satisfy preconceived theoretical expectations. Selection leads to a truncated pool of published studies, with the consequent suppression of some of the available empirical findings on a literature. In the context of union-profit effects, publication bias may theoretically take the form of researchers finding it difficult to publish manuscripts in which unions have no effect or a positive effect on profits. Economists have recently taken a very keen interest on the existence of selection effects in empirical economics research. Some examples include: Card and Krueger 1995; Ashenfelter et al. 1999; Görg and Strobl 2001; Ashenfelter and Greenstone 2004; Abreu et al. 2005; Doucouliagos 2005; Nijkamp and Poot 2005; Rose and Stanley 2005; Stanley 2005; and Mookerjee 2006. These investigations have found evidence of selection effects. One exception is Doucouliagos and Laroche (2003) in their meta-analysis of the union-productivity effects literature, who found that this literature was free of publication selectivity. With mounting evidence of selection effects in empirical economics and concerns that this can bias inferences drawn from evidence, researchers have developed techniques for the detection and correction of the effects of selection.

Following Card and Krueger (1995), Stanley (2001) develops a meta-significance model (MST) that is used to identify the existence of a genuine empirical effect within a literature. Stanley (2001) recommends estimating the following regression:

$$
\ln \left|t_{i}\right|=\alpha_{0}+\alpha_{1} \operatorname{lndf} f_{i}+\varepsilon_{i}
$$

where $t_{i}$ and $\mathrm{df}_{\mathrm{i}}$ denote the t-statistic and degrees of freedom from study $i$, respectively. The test is based on the logic that as sample size rises the precision of the estimate rises also, and hence, t-statistics also rise. Stanley (2005) shows that the slope coefficient in equation (2) offers information on the existence of genuine empirical effects, selection effects, or both. If $\alpha_{1}>0$, there is a genuine association between unions and profitability: $t$-statistics rise as precision rises only if a genuine empirical effect exists. If $\alpha_{1}<0$, the literature is contaminated by selection effects (t-statistics fall as precision rises). If $0<\alpha_{1}<0.5$, then there 
is a genuine association between unions and profitability, as well as selection in the literature. $^{5}$

It should be noted that the MST is a conservative test and shows only whether a genuine effect exists beyond selection effects. Moreover, since the dependent variable is the absolute value of the t-statistic, the slope coefficient measures only the strength of the association and not its direction.

\subsection{Precision Effect Tests (PET)}

Medical and behavioral researchers have extensively used a relatively simple MRA as a test for selection as well as genuine empirical effects net of selection:

$$
\hat{\eta}_{i}=\beta_{0}+\alpha_{0} S E_{i}+u_{i}
$$

(see for example Egger et al., 1997; Sutton et al., 2000; Rothstein et al., 2005). Testing whether $\alpha_{0}=0$ becomes the test for the presence of selection effects (see Stanley 2005 for details). Simulations show that the MRA estimate of $\beta_{0}$ in equation (3) also serves as a test for genuine empirical effect corrected for publication bias (Stanley 2007). Because $1 / S E_{i}$ is the precision of this estimate of empirical effect, this test $\left(\mathrm{H}_{0}: \beta_{0}=0\right)$ has been called by Stanley (2005) as the 'precision-effect test' (PET). Simulations also reveal that PET is very powerful and robust to the intensity of publication selection (Stanley 2007).

Smaller samples have larger standard errors. If selection is absent from a literature, no association between a study's reported effect and its standard error should appear (De Long and Lang 1992). However, if there is selection, smaller studies will search for larger effects in order to compensate for their larger standard errors, which can be done by modifying specifications, functional form, samples and even estimation technique.

The meta-regression equation (3) contains obvious heteroscedasticity, because $S E_{i}$ is the estimated standard deviation of $\hat{\eta}_{i}$, which must vary from observation to observation. Stanley (2005) recommends dividing equation (3) by $S E_{i}$ to obtain the weighted least squares (WLS) version of this MRA. This produces:

$$
t_{i}=\beta_{1}+\beta_{0}\left(1 / s_{i}\right)+v_{i}
$$


The coefficient on $1 / \mathrm{SE}, \beta_{0}$, in equation (4) is then the estimate of the union-profit effect corrected for selection effects (Stanley 2005).

Equations 2 and 4 become our basic estimating equations for quantifying the unionprofit effect, as well as the sources of such effects. Empirical profitability regressions (dropping the usual subscripts) take the following generic form:

$$
\pi=\beta_{0}+\beta_{\mathrm{u}} \mathrm{U}+\beta_{\mathrm{m}} \mathrm{M}+\beta_{\mathrm{i}} \mathrm{I}+\beta_{\mathrm{dm}} \mathrm{U}^{*} \mathrm{M}+\beta_{\mathrm{di}} \mathrm{U}^{*} \mathrm{I}+\beta_{\mathrm{z}} \mathrm{Z}+\mathrm{u}
$$

where $\pi$ is a measure of profits, $U$ is a measure of union presence, $M$ is a measure of market power, I is a measure of long lived investments (such as physical capital, R\&D and advertising) and $\mathrm{Z}$ are other factors that impact on profits. The main focus in the literature is on the $\beta_{\mathrm{u}}, \beta_{\mathrm{dm}}$ and $\beta_{\mathrm{di}}$ coefficients.

\section{Is there a union-profit effect and is it negative?}

Table 1 presents the MST results for the presence of union-profit effects, using the t-statistics associated with the $\beta_{\mathrm{u}}$ coefficients from equation 5. Column 1 reports the basic regression of $\ln \left|t_{i}\right|$ on $\operatorname{lndf}_{\mathrm{i}}$. The coefficient on $\operatorname{lndf}_{\mathrm{i}}$ should be positive and statistically significant for a genuine effect to be present. In column 2 we add the USA* $\operatorname{lndf}_{\mathrm{i}}$ term to detect regional differences. In this specification the coefficient on $\operatorname{lndf}_{\mathrm{i}}$ represents the rest of the world (ROW) and $\operatorname{lndf}_{\mathrm{i}}$ plus USA* $\operatorname{lndf}_{\mathrm{i}}$ represent the USA. ${ }^{6}$ In columns 3 and 4 we focus on only those estimates that used accounting based measures of profits (such as return on assets, ROA). In column 5 the focus is on only those estimates using market based measures of profits (such as Tobin's q). All of these used US data and, hence, ROW estimates are not available.

\section{TABLE 1 ABOUT HERE}

In all cases there is solid evidence of a union-profit effect for the USA. ${ }^{7}$ Note that the Wald test for $\operatorname{lndf}_{\mathrm{i}}+\mathrm{USA} * \operatorname{lndf}_{\mathrm{i}}$ is statistically significant and the sum of the coefficients is positive. This conclusion is supported by the PET results reported in Table 2. Column 1 presents the results of combining all estimates. A statistically significant negative sign on 1/SE indicates a negative union-profit effect. In column 2, USA/SE measures the size of the incremental union-profit effect for the USA and 1/SE for the ROW. Columns 3 and 4 present the results using only accounting based measures of profits, while column 5 presents the results for market based measures. From the PET results we can draw four robust 
conclusions. First, in all cases, the sum of the coefficients on 1/SE plus USA/SE is negative (and statistically significant) indicating that unions have a negative effect on profits in the USA. Second, the coefficient on 1/SE represents the union-profit effect for the ROW, which is also statistically significant. Third, the union-profit effect in the USA is much larger than it is in the ROW and its magnitude is of economic significance. Fourth, the union-profit effect in the USA is larger when market based measures of profits are used. That is, the long run effect of unions on profits is larger than it is in the short run $(-0.11<-0.08){ }^{8}$

\section{TABLE 2 ABOUT HERE}

The constant in Table 2 is in all cases statistically significant (except in column 5 where it is only very marginally so). This confirms the presence of selection effects. The negative sign on the constant indicates that the selection process is in favour of negative union-profit effects. Note, however, that the size of the selection effect is small. In all cases it is less than 1. Doucouliagos and Stanley (2007) show that selection effects that are less than 1 are trivial. Hence, while there is evidence of some selectivity in the union-profit effects literature, its effect on statistical inference will be minimal.

The last three rows of Table 2 present the weighted average partial correlations for all estimates, ROW estimates and US estimates, respectively. Comparing these to the PET we see only slight differences. In the union-profits effects literature, the raw averages are only slightly biased by the selection process. For example, in column 1 the raw average is -0.07 while the selection corrected average is -0.06 . This finding is consistent with that of Doucouliagos and Laroche (2003) and confirms that there is, fortunately, little selection in the union and performance literature. This finding stands in contrast with most of other investigations on selection in empirical economics.

We use the partial correlation as our measure of the union-profit effect as it can be calculated for all the reported estimates and, hence, enables a comprehensive assessment of the literature. Many of the studies do not offer enough information from which to calculate reliably the effect as a percent of profits. However, we estimated from a sub-set of the estimates the union-profit effect in percentage terms. Evaluated at 100 percent unionization, our best estimate of the impact of US unions is that they decrease profits by around 20 percent, which is clearly of a large economic significance. However, we hasten to add that it is an out-of-sample forecast as 100 percent unionization is rare. 


\section{What are the sources of union-profit effects?}

The hypothesis that unions capture monopoly rents requires two supporting pieces of evidence. First, it requires evidence that monopoly power increases profits. If monopoly power does not contribute to profits, than unions cannot appropriate them. In terms of equation $5, \beta_{\mathrm{m}}$ should be $>0$. Second, the interaction between unions and market power should be negative $\left(\beta_{\mathrm{dm}}<0\right)$. This means that unionized firms with market power should have lower profit rates than similar non-unionized firms. Likewise, the hypothesis that unions capture quasi-rents from long-lived assets and/or from intangible assets also requires the same two supporting pieces of evidence: It requires evidence that intangible assets increase profits $\left(\beta_{\mathrm{i}}>0\right)$ and that there is a negative coefficient on the interaction between unions and intangible assets $\left(\beta_{\mathrm{di}}<0\right)$.

\subsection{Market power, long lived assets and profitability}

There is a very large literature on the links between market power and profits, as well as the links between assets and profits. Our focus here is only on the sub-set of this literature that has explored also the impact of unions, as a meta-analysis of the entire market power-profits and assets-profits literatures is clearly beyond the scope of the present paper. Thus, our focus is on only those estimates that explore the impact of both unions and market power and unions and assets, as this is what we wish to test.

Table 3 presents the meta-analysis of the market power estimates for the MST and PET. These are based on the t-statistics associated with the $\beta_{\mathrm{m}}$ coefficients (from equation 5). Column 1 presents four averages of the partial correlations between market power and profitability - the simple mean (M), the median (Me) and two weighted averages. The first weighted average is constructed by using all the available estimates $\left(\mathrm{W}_{\mathrm{m}}\right)$. The second weighted average is constructed by omitting Hirsch (1991) $\left(\mathrm{W}_{\mathrm{h}}\right)$. This is undertaken for sensitivity analysis, as Hirsch (1991) uses a relatively large sample size. ${ }^{9}$ Column 2 presents the equivalent averages for the associated t-statistics. Columns 3, 4 and 5 present MST results, while the PET results are presented in columns 6,7 and 8 . The first set of results (panel A) relate to all estimates of the impact of market power on profitability, with and without the Hirsch (1991) study, combining estimates for industry concentration and market share together. Note that the coefficients on the constant are not presented - for the sake of brevity only the coefficient for $\operatorname{lndf}_{\mathrm{i}}$ is presented. ${ }^{10}$ Column 3 combines all studies, while studies using accounting measures and market measures are presented separately in columns 
4 and 5, respectively. In none of the six MST regressions is the coefficient on lndf positive and statistically significant. In the six FAT regressions, there is only one case of a positive and statistically significant effect between market power and profitability. When market based measures are used a positive association between market power and profitability is established.

The second set of results relates to the estimates of industry concentration (panel B). When all such estimates are used, the PET results confirm the presence of a genuine effect between industry concentration and profitability. The final set of results (panel C) relates to estimates using firm level market shares. The results suggest that there is a negative effect on profits, and this effect is larger in the US when market based measures are combined and Hirsch (1991) is excluded (-0.07). We conclude from the meta-analysis presented in Table 3 that the union-profits effect literature has established that industry concentration has a positive effect on profits and this may be a source for union-profit effects.

\section{TABLE 3 ABOUT HERE}

Table 4 presents a similar meta-analysis for tangible and intangible assets as a source of profits. These are based on the t-statistics associated with the $\beta_{\mathrm{i}}$ coefficients (from equation 5). When the estimates for both tangible and intangible assets are combined (panel A), the MST suggests a genuine effect for accounting based profit measures but this is supported by PET only if Hirsch is excluded and when accounting profits measures are used. The situation is similar for estimates relating to the association between physical capital stock and profitability. There is no evidence within this literature that capital intensity has a positive effect on profitability. The results for R\&D are interesting. All six MST regressions indicate that $R \& D$ has a genuine effect on profits. However, this conclusion is supported by PET only if Hirsch (1991) is excluded. ${ }^{11}$ When Hirsch (1991) is included, PET indicates that R\&D has a negative effect on accounting based measures of profits. Regardless of whether Hirsch (1991) is included or not, the results suggest that there is no association between R\&D and market based measures of profits. In contrast to $R \& D$, the meta-analysis for advertising indicates that there is a strong positive effect between advertising and accounting based measures of profits. We conclude from the meta-analysis presented in Table 4 that the unionprofits effect literature has established that: there is no association between tangible or intangible assets and market based measures of profitability. There is a positive effect on profits arising from advertising on accounting based measures of profits, and there is a 
similar effect from R\&D if Hirsch (1991) is ignored. These effects from R\&D and advertising may be sources for union-profit effects, although the R\&D result is not robust.

\section{TABLE 4 ABOUT HERE}

\subsection{Unions, market power and long live assets interactions}

Table 5 presents the meta-analysis for the union*market power and union*assets interaction terms. ${ }^{12}$ These are based on the t-statistics associated with the $\beta_{\mathrm{dm}}$ and $\beta_{\mathrm{dm}}$ coefficients (from equation 5). Recall that, for market power or long lived investment to be a source of profits, the union interaction terms should be negative. None of the union*market power interaction terms have the necessary statistically significant negative sign, and in only one case is the union*investment interaction with a statistically significant negative sign (-0.03 with t-stat 1.78, which is weakly statistically significant). We can conclude from both the MST and PET tests that the extant evidence has not proven that source of union-profit effects is either market power nor appropriation of quasi-rents from long lived assets.

\section{TABLE 5 ABOUT HERE}

\section{Explaining the pattern in the results}

In this section we use meta-regression analysis (MRA) to take a closer look at the variation in the reported empirical union-profit results and identify some of the sources of these differences. Meta-regression analysis is gaining widespread appeal among economists, and the union-profit effects literature is a fertile ground for its application. Recent examples of MRA include Gorg and Strobl (2001), Doucouliagos and Laroche (2003), Jarrell and Stanley (2004) and Dobson et al. (2006). MRA involves regressing a measure of the union-profit effect upon a set of potential explanatory variables.

We consider eleven potential explanatory variables in our meta-regression analysis: US is a binary variable taking the value of 1 if the estimates relate to US data. Manufacturing is a binary variable taking the value of 1 if the estimates relate purely to a manufacturing firm or industry. Firm Level is a binary variable taking the value of 1 if the estimates relate to firm level data (with industry level estimates as the base). Density is a binary variable taking the value of 1 if the study uses union density as the measure of unionization (with the use of a dummy for union presence as the base). Accounting is a binary variable taking the value of 1 if an accounting measure of performance was used (with market based measures as the base). 
Panel is a binary variable taking the value of 1 if panel data were used (with cross-sectional data as the base). $R \& D$, Advertising, Capital and Monopoly are binary variables taking the value of 1 if $R \& D$, advertising, capital stock and a measure of market power were included as controls, respectively. $O L S$ is included to capture the effect of different estimators.

The results are presented in Table 6, column 1 for the so-called Fixed Effects MRA and in column 2 for the so-called Random Effects MRA. In a Fixed Effects MRA, the heterogeneity in reported union-profit effects is assumed to arise purely from systematic differences across studies, as well as from random errors. The Random Effects MRA allows study effects to differ systematically according to specified covariates, as well as due to random factors that are not related to any covariates. ${ }^{13}$ That is, in a Random Effects metaanalysis model, study differences are assumed to result from sampling error, systematic differences due to the research process, as well as random differences between studies. To estimate the Random Effects model, we assume that the total variance in the union-profit effects consists of variance due to sampling error, as well as variance due to other factors that are randomly distributed. We used the standard error of each partial correlation to calculate the variance due to sampling error, and we estimate the second variance term using the socalled iterative restricted maximum likelihood method, or REML (see Raudenbush 1994 for details). Table 6 shows that both models point to a similar range of covariates, with similar coefficients.

The coefficient for US is negative and statistically significant. US studies report larger negative union-profit effects. Studies using manufacturing data find larger negative unionprofit effects - the impact of unions on profits is greater in this industry than it is in other industries. The use of firm level data does not result in qualitatively different results to the use of industry level data, once other study characteristics are controlled for. The measure of unions does play a difference, with the use of union density measures resulting in lower negative union-profit effects. ${ }^{14}$ Union density is a better measure than a simple dummy variable. Hence, the MRA results suggests that the use of unionization dummies biases estimates (magnifies the size of the negative union-profit effect). Panel and cross-sectional data produce the same union-profit effects, once other study characteristics are controlled for. Panel data capture short-run dynamics, while cross-sectional data capture long-run effects. Hence, the MRA results suggest that the short-run and long-run effect on unions on profits is similar. There is no effective difference in the union-profit effect between accounting and market based measures. The inclusion of $R \& D$ as a control variable and the inclusion of a measure of market power both have no effect on the reported union-profit effects. However, 
the inclusion of advertising results in larger negative union-profit effects, while the inclusion of capital results in lower negative union-profit effects.

The latter results are informative, as they represent channels through which unions can affect profits indirectly. To see how meta-analysis can inform on the existence of indirect channels, consider the following two specifications of a profitability regression (dropping the usual subscripts):

$$
\begin{aligned}
& \pi=\beta_{0}+\beta_{\mathrm{k}} \mathrm{K}+\beta_{\mathrm{u}} \mathrm{U}+\beta_{\mathrm{z}} \mathrm{Z}+\mathrm{u} \\
& \pi=\alpha_{0}+\alpha_{\mathrm{u}} \mathrm{U}+\alpha_{\mathrm{z}} \mathrm{Z}+\mathrm{v}
\end{aligned}
$$

where $\pi$ denotes profits, $\mathrm{U}$ is unions and $\mathrm{K}$ is capital and $\mathrm{Z}$ are other factors that impact on profits and where $\mathrm{K}$ is a function of unions. ${ }^{15}$ If a researcher estimates equation $7, \alpha_{\mathrm{u}}$ is the estimate of the total effect (direct plus indirect effects) of unions on profits. If a researcher estimates equation $6, \beta_{\mathrm{u}}$ is the estimate of the direct effect of unions on profit, with a further indirect channel on profits working through the impact of $\mathrm{U}$ on $\mathrm{K}$ and then from $\mathrm{K}$ to $\pi$. $^{16}$ Hence, when $\mathrm{K}$ is included as a control variable in an MRA model, the coefficient on $\mathrm{K}$ will show the impact of including $\mathrm{K}$ on the estimated union-profit effects. That is, the coefficient of $\mathrm{K}$ in an MRA will be an estimate of the indirect effect of unions on profits working through the K channel.

Hence, the positive coefficient of capital reported in Table 6 indicates that the direct union-profit effect is lower than the total union-profit effect. This means that there is a negative indirect effect of unions reducing capital, which in turn reduces profits. Similarly, the negative coefficient of advertising in Table 6 indicates that the direct union-profit effect is greater than the total union-profit effect. This means that there is positive indirect effect of unions increasing advertising, which in turn increases profits. These results then suggest that: (a) unions reduce tangible asset investments, a result that is consistent with the findings of Doucouliagos and Laroche (2003c); and (b) unions increase intangible assets in the form of expenditure on advertising.

It is surprising that given that unions are expected to affect tangible and intangible assets, that these associations have not been modeled more fully in the union-profit effects literature. It will be interesting for future research to develop and estimate systems of equations that enable the estimation of direct effects of unions on profits, as well as effects of unions on factor accumulation and, hence, the indirect effects on profits.

Column 3 of Table 6 reports fixed effects MRA for the union*market power interaction profit effects and column 4 reports a similar MRA for the union*capital assets 
interaction profit effects (grouping both tangible and intangible asset effects together). The number of observations is smaller for these regressions. Only Advertising has a statistically significant effect in column 3, implying that including advertising reduces the magnitude of the union*market power interaction effect. In column 4, density has a negative coefficient, implying that union*asset interaction effects are more negative when unionization is measured as density.

\section{TABLE 6 ABOUT HERE}

\section{SUMMARY}

This paper reports a comprehensive quantitative review of the union-profit effects literature. Meta-regression analysis was used to assess the extant empirical literature. Five conclusions can be drawn from the analysis. First, the results show conclusively that unions have a negative impact on financial performance. Second, the union-profit effect is stronger in the US than it is in the ROW. Third, there is inconclusive evidence regarding the source of union profits. Separate meta-analysis on market power and the tangible and intangible investments indicates that industry concentration, advertising and $R \& D$ all have a positive effect on profits. When unions interact with industry concentration they have a positive effect on profits and, hence, cannot be the source of negative union-profit effects. Some evidence was found that the source of union-profit effects may be intangible and tangible assets. However, while R\&D and advertising both have a positive effect on profits, the union-capital interactions are of weak statistical significance. Fourth, much of the variation in reported union-profit effects between studies can be explained by: regional effects (larger effects in the US); industry (larger effects in manufacturing); measurement differences (smaller effects if union density is used); and estimation (larger effects when OLS is used). Fifth, metaregression analysis suggests the presence of indirect effects, with unions affecting both physical capital formation and expenditure on advertising.

Our review and assessment of the union-profit effects literature also highlights three major weakness in this literature. First, there is a strong need more estimates for other countries. The marginal contribution of another conventional direct union-profit effect using US data is relatively small. The evidence appears to be solid that unions have a negative effect on profits in the US. Greater value will be generated from further studies using non-US data. What is the effect of unions on profits in countries which have received little or no investigation? Second, further research is needed to identify the sources of union-profit effects. The extant evidence in this area is still weak and our quantitative review does not 
place us that much further than when Hirsch (1991) noted the disagreement concerning the source of union gains. However, the benefit of meta-analysis is that it proves that none of the existing explanations is yet to be supported by the data. Perhaps the answer will come from either new theoretical explanations on the sources of union-profit effects or from additional evidence testing existing theories. Third, further research is needed to identify the direct and indirect channels through which unions affect profits. The meta-regression analysis identified two such indirect channels and additional primary research is clearly needed. The estimation of systems of equations that allow unions to affect profits directly, as well as indirectly through factor accumulation, promise to be fruitful avenues for future research.

\section{REFERENCES}

\subsection{Studies included in the meta-analysis}

Addison, J.T., Kraft K. and Wagner J. 1993. German Work councils and firm performance. in Kaufman B.E. and Kleiner M.M. (Eds), Employee Representation: Alternatives and Future Directions, Madison, Wisconsin, IRRA, pp.305-335.

Bae, J. and Lawler, J.J. 2000. Organizational and HRM strategies in Korea: impact on firm performance in an emerging economy. Academy of Management Journal 43:502-517.

Batt, R. and Welbourne T. 2002. Performance growth in entrepreneurial firms:revisiting the union-performance relationship. In J. Katz and Welbourne T. eds, Research Volume in Entrepreneurship, vol. 5, JAI Press.

Becker, B.E. and Olson C.A. 1992. Unions and firm profits. Industrial Relations 31:395-415.

Bronars S., Deere D. 1994. Unionization and profitability: Evidence of Spillover effects. Journal of Political Economy 102:15-37.

Brunello, G. 1992. The effect of unions on firm performance in Japanese manufacturing. Industrial and Labor Relations Review April, pp. 471-487.

Cable, J.R. and Machin S.J. 1991. The relationship between union wage and profitability. Economics Letters 32:75-79.

Caves, R., Porter M., Spence M. and Scott T. 1980. Competition in the Open Economy. Cambridge, Harvard University Press.

Chappell, W., Mayer W. and Shugart W. 1991. Union rents and market structure revisited. Journal of Labor Research 12:35-46. 
Chiles, T.W. and Stewart J.B. 1993. Union rent appropriation and ex-post analysis. Journal of Labor Research 14:317-334.

Clark, K. 1984. Unionization and firm performance: the impact on profits, growth and productivity. American Economic Review 74:893-919.

Connolly, R.A., Hirsch B.T. and Hirschey M. 1986. Union rent seeking, intangible capital and market value of the firm. Review of Economics and Statistics 68:567-577.

Conyon, M., Machin, S. 1991a. The determination of profit margins in UK manufacturing, Journal of Industrial Economics, 39:369-382.

Conyon, M., Machin, S. 1991b. Market structure and the empirical specification of profits margins, Economics Letters, 35:227-231.

Domowitz, I., Hubbard R.G. and Petersen B.C. 1986. The intertemporal stability of the concentration-margins relationship. Journal of Industrial Economics 35:13-34.

Dowrick, S. 1989. Union-oligopoly bargaining, Economic Journal, 99:1123-1142.

Fitzroy, F. and Kraft K. 1985. Unionization, wages and efficiency. Kyklos 38:537-553.

Fitzroy, F. and Kraft K. 1986. Profitability and profit sharing: theories and evidence from the US and West Germany. The Journal of Industrial Economics 35:113-130.

Fitzroy, F. and Kraft K. 1993. Economic effects of Co-determination. Scandinavian Journal of Economics 95:365-375.

Ghosal, V. 1989. Market structure, Price-cost margin and unionism: an empirical note. Economic Letters 29:179-182.

Gittell, J.H., Von Nordenflycht and Kochan T. 2004. Mutual gains or zero sum? Labor relations and firm performance in the Airline Industry. Industrial and Labor Relations Review 57:163-180.

Guest, D.E., Michie J., Conway N. and Sheehan M. 2003. Human Resource Management and Corporate Performance in UK. British Journal of Industrial Relations 41:291-314.

Harel, G.H. and Tzafrir S.S. 1999. The effect of human resource management practices on the perceptions of organizational and market performance of the firm. Human Resource Management 38:185-200.

Haskel, J.E., Martin, C. 1995. Price, marginal cost and the business cycle. Oxford Bulletin of Economics and Statistics, 57:25-41.

Hirsch, B.T. 1990. Market structure, union rent seeking and firm profitability. Economics Letters 32:75-79.

Hirsch, B.T. 1991a. Union coverage and profitability among US firms. Review of Economics and Statistics 73:69-77. 
Hirsch, B. 1991b. Labor Unions and the Economic Performance of Firms, W.E. Upjohn Institute for Employment Research, Kalamazoo, Michigan.

Hirsch, B.T. and Connolly R.A. 1987. Do unions capture monopoly profits? Industrial and Labor Relations Review 41:118-136.

Huselid, M.A. 1995. The impact of human resource management practices on turnover, productivity, and corporate financial performance. Academy of Management Journal 38:635-672.

Karahasan, N. 1995. The effect of unionisation on the profitability: The US manufacturing firms, 1986-1988. Journal of Economics 21:71-79.

Karier, T. 1985. Unions and monopoly profits. Review of Economics and Statistics 67:34-42.

Karier, T. 1988. New evidence on the effect of unions and imports on monopoly power. Journal of Post Keynesian Economics 10:414-427.

Kleiner, M.M., Lee Y-M. 1997. Work councils and unionization: Lessons from South Korea, Industrial Relations, 36: 1-16.

Laporta, P. and Jenkins A. 1996. Unionization and profitability in the Canadian sector. Relations Industrielles 51:756-777.

Laroche, P. 2004. Présence syndicale et performance financière des entreprises: une analyse statistique sur le cas français. Finance-Contrôle-Stratégie, 7 : 117-145.

MacDonald, J.T. 1999. The determinants of firms' profitability in Australian manufacturing. Economic Record 75:115-126.

MacDonald, J.T. and Bloch, H. 1999. The spillover effects of Industrial action on firm profitability. Review of Industrial Organization 15:183-200.

Machin, S. J. 1991. Unions and the capture of economic rents: An investigation using British firm level data. International Journal of Industrial Organization 9:261-274.

Maki, D.R. and Meredith L.N. 1986. The effect of unions on profitability: Canadian evidence. Relations Industrielles 41:54-68.

Menezes-Filho, N. A. 1997. Unions and profitability over the 1980s: Some Evidence on Union-firm Bargaining in the United Kingdom. The Economic Journal 107:651-670.

Morishima, M. 1991. Information sharing and firm performance in Japan. Industrial Relations 30:37-61.

Salinger, M.A. 1984. Tobin's q, unionisation and the concentration-profits relationship. Rand Journal of Economics 15:159-170.

Voos, P.B. and Mishel L.R. 1986a. The union impact on profits in the supermarket industry. Review of Economics and Statistics 68: 513-517. 
Voos, P.B. and Mishel L.R. 1986b. The union impact on profits: evidence from industry price-cost margin data. Journal of Labor Economics 4:105-133.

\subsection{Other references}

Adams, D.C., Gurevitch, J. and Rosenberg, M.S. 1997. Resampling tests for meta-analysis of ecological data. Ecology 78:1277-83.

Allen, S. G. 1986. Union work rules and efficiency in the building trades. Journal of Labor economics 4:212-240.

Allen, S. G. 1988. Further evidence on union efficiency in construction. Industrial Relations, 27:232-240.

Becker, B. 1987. Concession Bargaining: The impact on Shareholder's equity. Industrial and Labor Relations Review 40:268-279.

Becker, B. 1995. Union rents as a source of takeover gains among target shareholders. Industrial and Labor Relations Review 49:3-19.

Becker, B. and Olson C. 1987. Labor Relation and Firm Performance. In Kleiner et al. eds, Human Resources and the performance of the firm, IRRA, Madison, pp. 43-85.

Becker, B. and Olson C. 1989. Unionization and shareholder Interests. Industrial and Labor Relations Review 42:246-261.

Booth, A.L. 1995. The Economics of the Trade Union. Cambridge University Press.

Bronars, S., and Deere D. 1991. The threat of unionisation, the use of debt and the preservation of shareholder wealth. Quarterly Journal of Economics 106:213-254.

Bronars, S., Deere D.R. and Tracy J. 1994. The effects of unions on firm behavior: an empirical analysis using firm-level data. Industrial Relations 33: 426-451.

Bryson, A. and Wilkinson, D. 2001. Collective Bargaining and Workplace Performance: an investigation using the Workplace Employee Relations Survey 1998. Employment Relations Research Series No. 12, Department of Trade and Industry Research Series.

Cavanaugh, J.K. 1998. Asset specific investment and Unionized Labor. Industrial Relations, 37: $35-50$.

Card, D. and Krueger A.B. 1995. Time-Series Minimum-Wage Studies: A Meta-Analysis. American Economic Review 85:238-43.

De Long, J.B. and Lang, K. 1992. Are all economic hypotheses false? Journal of Political Economy 100:1257-72. 
Djankov, S. and Murrell, P. 2002. Enterprise Restructuring in Transition: A quantitative survey. Journal of Economic Literature 40:739-92.

Dobson, S., Ramlogan, C. and Strobl, E. 2006. Why Do Rates of (b)-Convergence Differ? A meta-regression analysis. Scottish Journal of Political Economy. 53, 153-73.

Doucouliagos, C. 1995. Worker Participation and Productivity in Labor-Managed and Participatory Capitalist Firms: A Meta-Analysis. Industrial and Labor Relations Review 49:58-77.

Doucouliagos C. and Laroche P. 2003a. What do unions do to productivity? a meta-analysis. Industrial Relations 42:650-691.

Doucouliagos C. and Laroche P. 2003b. Unions and Productivity Growth: A Meta-Analytic Review", in Kato T. and Pliskin J. (eds), The determinants of the incidence and the effects of participatory organization, vol. 7, JAI Book series, Elsevier Science, pp. 5782.

Doucouliagos, C. and Stanley, T.D. 2007. Theory Competition and Selectivity, Economics Working Paper, Deakin University.

Dow, G. 1993. Why Capital Hires Labour: A Bargaining Perspective. American Economic Review 83:118-134.

Eaton, B. 1972. The worker and the profitability of the strike. Industrial and Labor Relations Review, 26:670-679.

Efron, B. and R. J. Tibshirani 1993. An Introduction to the Bootstrap, Chapman and Hall, San Francisco.

Egger, M., Smith, G.D., Scheider, M., and Minder, C. 1997. Bias in meta-analysis detected by a simple, graphical test. British Medical Journal 316:629-34.

Florkowski, G.W. and Kuldeep Shastri. 1992. Stock-price response to profit sharing in unionized settings. Journal of Labor Research 13:407-420.

Freeman, R.B. 1983. Unionism, price-cost margin and the return to capital, Working paper $\mathrm{n}^{\circ} 1164$, National Bureau of Economic Research.

Freeman, R. B. and Medoff J. 1984. What do unions do?, New York, Basic Books.

Frick, D. and Sadowski D. 1995. Works councils, unions and firm performance: The impact of workers' participation in Germany. In Buttler et al. (Eds), Institutional Frameworks and Labor Market Performance, London: Routledge, pp. 46-81.

Gorg, H. and Strobl, E., 2001. Multinational Companies and Productivity: a meta-analysis. The Economic Journal 111:723-39 
Grabowski, H.G. and Mueller D.C. 1978. Industrial research and development, intangible capital stocks and firm profit rates. Bell Journal of Economics 9:328-343.

Gurdon, M.A. and Rai A. 1990. Co-determination and enterprise performance: Empirical evidence from West Germany. Journal of Economics and Business 42:289-302.

Hassel, A. 1999. The erosion of the German system of industrial relations. British Journal of Industrial Relations 37:483-505.

Hirsch, B. and Addison J. 1986. The Economic Analysis of Unions: New Approaches and Evidence, London, Allen \& Unwin.

Hirsch, B. and Morgan B. 1994. Shareholders Risks and Returns in Union and Nonunion Firms. Industrial and Labor Relation Review 47: 302-318.

Hunter, John E. and Frank L. Schmidt. 1990. Methods of Meta-Analysis: correcting error and bias in research findings, Sage publications.

Jarrell, S.B. and Stanley T.D. 1990. A meta-analysis of the union-nonunion wage gap. Industrial and Labor Relations Review 44: 54-68.

Jarrell, S. and Stanley, T.D., 2004. Declining Bias and Gender Wage Discrimination? A Meta-regression analysis. Journal of Human Resources, 39, 828-38

Karier, T. 1991. Unions and the U.S. comparative advantage. Industrial Relations 30(1), Winter.

Kleiner, M. 2001. Intensity of management resistance: understanding the decline of unionization in the Private sector. Journal of Labor Research 22: 519-540.

Kerkviet, J. and MacMullen B.S. 1997. The impact of unionisation on motor carrier costs. Economic Inquiry 35:271-283.

Kochan, T.A., McKersie R. et Cappelli P. 1984. Strategic Choice and Industrial Relations Theory. Industrial Relations vol. 23:16-39.

Lewis, H.G. 1963. Unionism and Relative Wages in the United States: An empirical inquiry, Chicago, University of Chicago Press.

Lewis H.G. 1986. Union Relative Wage Effects: a survey, Chicago, University of Chicago Press.

Metcalf, D. 2003. Unions impact and implications for future membership. In P. Gregg and J. Wadsworth (Eds), The state of working Britain, $2^{\text {nd }}$ edition.

Moore, J. 1995. Labor union elections and corporate financial performance, Studies on Industrial Productivity, NY and London: Garland, pages XVII.

Raudenbush, S.W. 1994. Random effects models. In The Handbook of Research Synthesis. Cooper, H. and Hedges, L.V. (eds). Russell Sage Foundation: New York. 
Register C. A. 1988. Wages, productivity and costs in union and nounion hospitals. Journal of Labor Research 9: 325-345.

Rothstein, H.R., Sttton, A.J. and Borenstein, M. 2005. Publication Bias in Meta-Analysis: Prevention, Assessment and Adjustment. John Wiley and Sons, Chichester.

Ruback, R.S. and Zimmerman. 1984. Unionization and profitability: evidence from the capital market. Journal of Political Economy 92:1134-1157.

Sapsford, D. 1986. Some further evidence on the role of profits in union growth equations. Applied Economics 18: 27-36.

Shalev, M. 1980. Trade unionism and Economic analysis: the case of industrial conflict. Journal of Labor Research 1: 133-174.

Sloan, F. and Adamache K. 1984. The role of unions in hospital cost inflation. Industrial and Labor Relations Review, January, pp. 252-262.

Stanley, T.D. and Stephen B. Jarell. 1998. Gender Wage Discrimination Bias? a metaregression analysis. The Journal of Human Resources 33:947-973.

Stanley, T.D. 2001. Wheat From Chaff: meta-analysis as quantitative literature review. The Journal of Economic Perspectives 15:131-150.

Stanley, T.D. 2005. Beyond Publication Bias. Journal of Economic Surveys 19:309-45.

Stanley, T.D. 2007. Meta-regression methods for detecting and estimating empirical effects in the presence of publication selection. Oxford Bulletin of Economics and Statistics. forthcoming.

Sutton, A.J. et al., 2000. Methods for Meta-Analysis in Medical Research. Chichester: John Wiley and Sons.

Tachibanaki, T. and Noda T. 2000. The economic effects of trade union in Japan, MacMillan Press.

Thomas, S.L. and Kleiner M.M. 1992. The effect of two-tier collective bargaining agreements on shareholder equity. Industrial and Labor Relations Review 45: 339351.

Turnbull, P. 2003. What Do Unions Do Now? Journal of Labor Research 24: 491-527.

Voos, P. 1984. Union organizing: costs and benefits. Industrial and Labor Relations Review, 38:52-63.

Wolf, F.M. 1986. Meta-Analysis: Quantitative methods for research synthesis, Sage University Paper $n^{\circ} 59$.

Walton, R.E. and McKersie, R.B. 1965. A behavioral theory of labor negociations. An analysis of a social interaction system, New York, McGraw Hill. 
Zax, J. and Ichniowski C. 1988. The effect of public sector unionism on pay, employment, department budget and municipal expenditures. In Freeman and Ichniowski (eds), When Public Sector Workers Unionize, NBER, Chicago: The University of Chicago Press.

Table 1: $\quad$ Meta-Significance Tests, Unions and Profits (Dependent variable $=\ln \left|t_{i}\right|$ )

\begin{tabular}{|c|c|c|c|c|c|}
\hline Variable & $\begin{array}{c}\text { All estimates } \\
\text { (1) }\end{array}$ & $\begin{array}{c}\text { All estimates } \\
\text { (2) }\end{array}$ & $\begin{array}{l}\text { Accounting } \\
\text { (3) }\end{array}$ & $\begin{array}{c}\text { Accounting } \\
\text { (4) }\end{array}$ & $\begin{array}{c}\text { Market based } \\
\text { (5) }\end{array}$ \\
\hline Constant & $-1.22(-4.25)^{*}$ & $-0.23(-0.55)$ & $-0.86(-2.84)^{*}$ & $-0.24(-0.57)$ & $-2.33(-3.51)^{*}$ \\
\hline $\operatorname{lndf}_{\mathrm{i}}$ & $0.28(5.91)^{*}$ & $0.07(1.16)$ & $0.22(4.47)^{*}$ & $0.08(1.21)$ & - \\
\hline USA & - & $-1.79(-3.25)^{*}$ & - & $-1.51(-2.60)^{*}$ & - \\
\hline $\mathrm{USA}^{*} \operatorname{lndf}_{\mathrm{i}}$ & - & $0.36(4.13)^{*}$ & - & $0.33(3.56)^{*}$ & $0.47(4.18)^{*}$ \\
\hline Wald-USA $_{\text {-US }}$ & - & $53.91[0.00]$ & - & $5.67[0.02]$ & - \\
\hline $\mathbf{N}$ & 532 & 532 & 343 & 343 & 179 \\
\hline Adjusted $\mathbf{R}^{2}$ & 0.08 & 0.12 & 0.06 & 0.12 & 0.13 \\
\hline
\end{tabular}

Notes: $*$ denotes statistical significance at least at the $10 \%$ level. t-statistics in brackets, using robust standard errors derived from application of the bootstrap, with 1000 replications. Wald-usa tests the hypothesis that $\operatorname{lndf_{i}}+U_{S A} * \operatorname{lndf}_{i}=0$. Figures in squared brackets report prob-value for Wald -USA. $_{\text {. }} \mathrm{N}$ is the number of estimates.

Table 2: $\quad$ Precision Effect Tests (PET), Unions and Profits (Dependent variable $=t_{i}$ )

\begin{tabular}{lccccc}
\hline Variable & $\begin{array}{c}\text { All estimates } \\
\mathbf{( 1 )}\end{array}$ & $\begin{array}{c}\text { All estimates } \\
\mathbf{( 2 )}\end{array}$ & $\begin{array}{c}\text { Accounting } \\
\mathbf{( 3 )}\end{array}$ & $\begin{array}{c}\text { Accounting } \\
\mathbf{( 4 )}\end{array}$ & $\begin{array}{c}\text { Market based } \\
\mathbf{( 5 )}\end{array}$ \\
\hline Constant & $-0.72(-4.54)^{*}$ & $-0.62(-3.96)^{*}$ & $-0.70(-3.78)^{*}$ & $-0.67(-3.80)^{*}$ & $-0.43(-1.65)^{*}$ \\
1/SE & $-0.06(-6.07)^{*}$ & $-0.01(-2.14)^{*}$ & $-0.04(-4.56)^{*}$ & $-0.01(-1.88)^{*}$ & - \\
USA/SE & - & $-0.08(-7.30)^{*}$ & - & $-0.07(-5.51)^{*}$ & $-0.11(-5.82)^{*}$ \\
\hline Wald & - & $57.54[0.00]$ & - & $32.52[0.00]$ & - \\
N & 532 & 532 & 343 & 343 & 179 \\
Adjusted R & 0.16 & 0.30 & 0.11 & 0.26 & 0.37 \\
$\mathbf{r}_{\mathbf{w}-\text { All estimates }}$ & -0.07 & -0.07 & -0.06 & -0.06 & - \\
$\mathbf{r}_{\mathbf{w} \text { - Row estimates }}$ & -0.02 & -0.02 & -0.02 & -0.02 & - \\
$\mathbf{r}_{\mathbf{w} \text { - US estimates }}$ & -0.10 & -0.10 & -0.09 & -0.09 & -0.13 \\
\hline
\end{tabular}

Notes: * denotes statistical significance at least at the $10 \%$ level. t-statistics in brackets, using robust standard errors derived from application of the bootstrap, with 1000 replications. Wald -USA $_{\text {a }}$ tests the hypothesis that $1 / \mathrm{SE}+\mathrm{USA} / \mathrm{SE}=0$. Figures in squared brackets report prob-value for Wald-USA. $\mathrm{N}$ is the number of estimates. $\mathrm{r}_{\mathrm{w}}$ denotes the weighted average partial correlation using sample size as weights. 
Table 3: Market Power and Profitability, Meta-Significance and Precision Effect Tests, (Dependent Variable $=\ln \left|t_{i}\right|$ for MST and $t_{i}$ for PET)

\begin{tabular}{|c|c|c|c|c|c|c|c|c|}
\hline \multirow[t]{2}{*}{$\begin{array}{c}\text { Market Power } \\
\text { Measure }\end{array}$} & \multirow{2}{*}{$\begin{array}{l}\text { Average } \\
\text { r } \\
(1)\end{array}$} & \multirow{2}{*}{$\begin{array}{l}\text { Average } \\
\text { t-statistic } \\
\text { (2) }\end{array}$} & \multicolumn{3}{|c|}{$\begin{array}{l}\text { Coefficients } \\
\text { on } \operatorname{lndf} f_{\mathbf{i}}\end{array}$} & \multicolumn{3}{|c|}{$\begin{array}{c}\text { Coefficients } \\
\text { on } 1 / \mathrm{SE}_{\mathbf{i}}\end{array}$} \\
\hline & & & $\begin{array}{c}\text { All } \\
\text { Studies } \\
\text { (3) }\end{array}$ & $\begin{array}{l}\text { Accounting } \\
\text { Measures } \\
\text { (4) }\end{array}$ & $\begin{array}{c}\text { Market } \\
\text { Measures } \\
\text { (5) }\end{array}$ & $\begin{array}{c}\text { All } \\
\text { Studies } \\
(6)\end{array}$ & $\begin{array}{c}\text { Accounting } \\
\text { Measures } \\
\text { (7) }\end{array}$ & $\begin{array}{c}\text { Market } \\
\text { Measures } \\
(8)\end{array}$ \\
\hline \multirow[t]{2}{*}{$\begin{array}{l}\text { A. } \\
\text { Market Power }\end{array}$} & $\begin{array}{l}\text { M: }+0.04 \\
\text { Me: }+0.03 \\
\mathrm{~W}_{\mathrm{m}}:+0.02\end{array}$ & $\begin{array}{l}\text { M: } 0.58 \\
\text { Me: } 0.75 \\
\mathrm{~W}_{\mathrm{m}}: 1.08\end{array}$ & $\begin{array}{c}0.02 \\
(0.50)\end{array}$ & $\begin{array}{c}0.06 \\
(1.11)\end{array}$ & $\begin{array}{c}-0.03 \\
(-0.42)\end{array}$ & $\begin{array}{c}0.01 \\
(0.74)\end{array}$ & $\begin{array}{c}-0.01 \\
(-0.40)\end{array}$ & $\begin{array}{c}0.03 \\
(1.99)^{*}\end{array}$ \\
\hline & $\mathrm{W}_{\mathrm{h}}:+0.01$ & $\mathrm{~W}_{\mathrm{h}}: 0.23$ & $\begin{array}{l}-0.01 \\
(-0.25)\end{array}$ & $\begin{array}{l}0.05 \\
(0.96)\end{array}$ & $\begin{array}{c}-0.15 \\
(-1.96)^{*}\end{array}$ & $\begin{array}{c}-0.01 \\
(-1.06)\end{array}$ & $\begin{array}{c}-0.02 \\
(-1.15)\end{array}$ & $\begin{array}{c}-0.01 \\
(-1.22)\end{array}$ \\
\hline - Adj. $R^{2}$ & - & - & $\begin{array}{c}0.00 \\
{[0.00]}\end{array}$ & $\begin{array}{c}0.00 \\
{[0.00]}\end{array}$ & $\begin{array}{c}0.00 \\
{[0.03]}\end{array}$ & $\begin{array}{c}0.00 \\
{[0.00]}\end{array}$ & $\begin{array}{c}0.00 \\
{[0.01]}\end{array}$ & $\begin{array}{c}0.06 \\
{[0.00]}\end{array}$ \\
\hline$-N$ & - & - & $\begin{array}{l}313 \\
{[295]}\end{array}$ & $\begin{array}{c}170 \\
{[161]}\end{array}$ & $\begin{array}{c}143 \\
{[134]}\end{array}$ & $\begin{array}{c}311 \\
{[293]}\end{array}$ & $\begin{array}{c}170 \\
{[160]}\end{array}$ & $\begin{array}{c}143 \\
{[134]}\end{array}$ \\
\hline \multirow[t]{2}{*}{$\begin{array}{l}\text { B. } \\
\text { Concentration } \\
\text { (Industry) }\end{array}$} & $\begin{array}{l}\text { M: }+0.03 \\
\text { Me: }+0.03 \\
\mathrm{~W}_{\mathrm{m}}:+0.04\end{array}$ & $\begin{array}{l}\text { M: } 0.62 \\
\text { Me: } 0.83 \\
\mathrm{~W}_{\mathrm{m}}: 2.28\end{array}$ & $\begin{array}{c}0.13 \\
(2.76)^{*}\end{array}$ & $\begin{array}{c}0.12 \\
(2.35)^{*}\end{array}$ & $\begin{array}{c}0.11 \\
(1.28)\end{array}$ & $\begin{array}{c}0.04 \\
(4.31)^{* * *}\end{array}$ & $\begin{array}{c}0.02 \\
(2.40)^{*}\end{array}$ & $\begin{array}{c}0.07 \\
(2.96)^{*}\end{array}$ \\
\hline & $\mathrm{W}_{\mathrm{h}}:+0.02$ & $\mathrm{~W}_{\mathrm{h}}: 1.16$ & $\begin{array}{c}0.06 \\
(1.43)\end{array}$ & $\begin{array}{c}0.09 \\
(1.70)^{*}\end{array}$ & $\begin{array}{l}-0.02 \\
(-0.22)\end{array}$ & $\begin{array}{c}0.02 \\
(3.05)^{*}\end{array}$ & $\begin{array}{l}0.01 \\
(1.45)\end{array}$ & $\begin{array}{c}0.01 \\
(1.07)\end{array}$ \\
\hline - Adj. $R^{2}$ & - & - & $\begin{array}{c}0.03 \\
{[0.00]}\end{array}$ & $\begin{array}{c}0.03 \\
{[0.01]}\end{array}$ & $\begin{array}{c}0.01 \\
{[-0.01]}\end{array}$ & $\begin{array}{c}0.13 \\
(0.03)\end{array}$ & $\begin{array}{c}0.05 \\
{[0.00]}\end{array}$ & $\begin{array}{c}0.23 \\
{[0.00]}\end{array}$ \\
\hline$-\mathrm{N}$ & - & - & $196[186]$ & 102 [97] & 94 [89] & 198 [186] & 102 [97] & 94 [89] \\
\hline \multirow[t]{2}{*}{$\begin{array}{l}\text { C. } \\
\text { Market Share } \\
\text { (Firm) }\end{array}$} & $\begin{array}{l}\text { M: }+0.06 \\
\text { Me: }+0.04 \\
\mathrm{~W}_{\mathrm{m}}:-0.01\end{array}$ & $\begin{array}{l}\text { M: } 0.51 \\
\text { Me: } 0.73 \\
\mathrm{~W}_{\mathrm{m}}:- \\
0.46\end{array}$ & $\begin{array}{l}-0.11 \\
(-1.54)\end{array}$ & $\begin{array}{l}-0.01 \\
(-0.07)\end{array}$ & $\begin{array}{c}-0.30 \\
(-2.55)^{*}\end{array}$ & $\begin{array}{c}-0.04 \\
(-2.21)^{*}\end{array}$ & $\begin{array}{c}-0.04 \\
(-1.65)\end{array}$ & $\begin{array}{l}-0.03 \\
(-1.62)\end{array}$ \\
\hline & $\mathrm{W}_{\mathrm{h}}:-0.01$ & $\mathrm{~W}_{\mathrm{h}}:-0.96$ & $\begin{array}{l}-0.11 \\
(-1.19)\end{array}$ & $\begin{array}{c}0.02 \\
(0.02)\end{array}$ & $\begin{array}{c}-0.44 \\
(-2.80)^{*}\end{array}$ & $\begin{array}{c}-0.06 \\
(-2.39)^{*}\end{array}$ & $\begin{array}{c}-0.05 \\
(-1.79)^{*}\end{array}$ & $\begin{array}{c}-0.07 \\
(-3.70)^{*}\end{array}$ \\
\hline - Adj. $R^{2}$ & - & - & $\begin{array}{c}0.01 \\
{[0.01]}\end{array}$ & $\begin{array}{c}0.00 \\
{[0.00]}\end{array}$ & $\begin{array}{c}0.16 \\
{[0.23]}\end{array}$ & $\begin{array}{c}0.09 \\
{[0.14]}\end{array}$ & $\begin{array}{l}0.06 \\
{[0.09]}\end{array}$ & $\begin{array}{c}0.05 \\
{[0.18]}\end{array}$ \\
\hline$-N$ & - & - & 115 [107] & $68(64)$ & $47(43)$ & $\begin{array}{c}115 \\
{[107]}\end{array}$ & 68 [64] & 47 [43] \\
\hline
\end{tabular}

Notes: $\mathrm{M}=$ mean. $\mathrm{Me}=$ Median. $\mathrm{W}_{\mathrm{m}}=$ Sample size weighted mean. $\mathrm{W}_{\mathrm{h}}=$ weighted mean without Hirsch (1991). *Denotes statistical significance at least at the $10 \%$ level. t-statistics reported in brackets using robust standard errors derived from applying the bootstrap. $\mathrm{N}$ is the number of estimates. The adjusted $\mathrm{R}$-squared and $\mathrm{N}$ figures reported in squared brackets relate to results without Hicks (1991). 
Table 4: Intangible and Long-Lived Assets and Profitability, Meta-Significance and Precision Effect Tests

(Dependent Variable $=\ln \left|t_{i}\right|$ for MST and $t_{i}$ for PET)

\begin{tabular}{|c|c|c|c|c|c|c|c|c|}
\hline \multirow[t]{2}{*}{$\begin{array}{c}\text { Asset } \\
\text { Measure }\end{array}$} & \multirow{2}{*}{$\begin{array}{c}\text { Average } \\
\mathrm{r} \\
(1)\end{array}$} & \multirow{2}{*}{$\begin{array}{c}\text { Average } \\
\text { t-statistic } \\
\text { (2) }\end{array}$} & \multicolumn{3}{|c|}{$\begin{array}{c}\text { Coefficients } \\
\text { on lndf }\end{array}$} & \multicolumn{3}{|c|}{$\begin{array}{c}\text { Coefficients } \\
\text { on } 1 / \mathrm{SE} \\
\end{array}$} \\
\hline & & & $\begin{array}{c}\text { All } \\
\text { Studies } \\
\text { (3) }\end{array}$ & $\begin{array}{l}\text { Accounting } \\
\text { Measures } \\
\text { (4) }\end{array}$ & $\begin{array}{c}\text { Market } \\
\text { Measures } \\
(5)\end{array}$ & $\begin{array}{c}\text { All } \\
\text { Studies } \\
(6)\end{array}$ & $\begin{array}{c}\text { Accounting } \\
\text { Measures } \\
(7)\end{array}$ & $\begin{array}{c}\text { Market } \\
\text { Measures } \\
(8)\end{array}$ \\
\hline \multirow{3}{*}{$\begin{array}{l}\text { A. } \\
\text { Tangible \& } \\
\text { Intangible } \\
\text { Assets }\end{array}$} & $\mathrm{M}:+0.18$ & M: 3.40 & 0.14 & 0.19 & 0.04 & $\begin{array}{l}-0.01 \\
\end{array}$ & 0.01 & -0.01 \\
\hline & $\begin{array}{l}\text { Me: }+0.17 \\
\mathrm{~W}_{\mathrm{m}}:+0.07\end{array}$ & $\begin{array}{l}\text { Me: } 3.00 \\
\mathrm{~W}_{\mathrm{m}}: 2.55\end{array}$ & $(2.86)^{*}$ & $(2.88)^{*}$ & $(0.51)$ & $(-0.06)$ & $(0.22)$ & $(-0.54)$ \\
\hline & $\mathrm{W}_{\mathrm{h}}:+0.15$ & $\mathrm{~W}_{\mathrm{h}}: 6.37$ & $\begin{array}{c}0.18 \\
(2.46)^{*}\end{array}$ & $\begin{array}{c}0.22 \\
(2.40)^{*}\end{array}$ & $\begin{array}{c}0.06 \\
(0.50)\end{array}$ & $\begin{array}{c}0.07 \\
(1.50)\end{array}$ & $\begin{array}{c}0.12 \\
(2.32)^{*}\end{array}$ & $\begin{array}{l}0.01 \\
(0.15)\end{array}$ \\
\hline - Adj. $R^{2}$ & - & - & $\begin{array}{c}0.03 \\
{[0.03]}\end{array}$ & $\begin{array}{c}0.06 \\
{[0.05]}\end{array}$ & $\begin{array}{c}0.00 \\
\lceil 0.00]\end{array}$ & $\begin{array}{c}0.00 \\
{[0.07]}\end{array}$ & $\begin{array}{c}0.00 \\
{[0.17]}\end{array}$ & $\begin{array}{c}0.00 \\
{[0.00]}\end{array}$ \\
\hline$-\mathrm{N}$ & - & - & 291 [267] & $168[156]$ & $\begin{array}{c}123 \\
{[111]}\end{array}$ & $\begin{array}{c}291 \\
{[267]}\end{array}$ & 168 [156] & $\begin{array}{c}123 \\
{[111]}\end{array}$ \\
\hline \multirow[t]{2}{*}{$\begin{array}{l}\text { B. Physical } \\
\text { Capital }\end{array}$} & $\begin{array}{l}\text { M: }+0.17 \\
\text { Me: }+0.10 \\
\mathrm{~W}_{m}:+0.04\end{array}$ & $\begin{array}{l}\text { M: } 3.33 \\
\text { Me: } 3.28 \\
W_{m}: 0.54\end{array}$ & $\begin{array}{c}0.10 \\
(1.30)\end{array}$ & $\begin{array}{c}0.24 \\
(2.30)^{*}\end{array}$ & $\begin{array}{c}-0.17 \\
(-1.88)^{*}\end{array}$ & $\begin{array}{c}-0.03 \\
(-1.55)\end{array}$ & $\begin{array}{c}-0.04 \\
(-1.46)\end{array}$ & $\begin{array}{c}-0.03 \\
(-0.72)\end{array}$ \\
\hline & $\mathrm{W}_{\mathrm{h}}:+0.12$ & $\mathrm{~W}_{\mathrm{h}}: 4.49$ & $\begin{array}{c}0.59 \\
(1.50)\end{array}$ & $\begin{array}{c}0.26 \\
(1.76)^{*}\end{array}$ & $\begin{array}{c}-0.21 \\
(-1.77)^{*}\end{array}$ & $\begin{array}{c}0.02 \\
(0.65)\end{array}$ & $\begin{array}{c}0.04 \\
(1.59)\end{array}$ & $\begin{array}{c}0.01 \\
(0.07)\end{array}$ \\
\hline - Adj. $R^{2}$ & - & - & $\begin{array}{c}0.01 \\
{[0.01]}\end{array}$ & $\begin{array}{c}0.06 \\
{[0.05]}\end{array}$ & $\begin{array}{c}0.04 \\
{[0.02]}\end{array}$ & $\begin{array}{c}0.02 \\
{[0.00]}\end{array}$ & $\begin{array}{l}0.02 \\
{[0.01]}\end{array}$ & $\begin{array}{c}0.00 \\
{[0.00]}\end{array}$ \\
\hline$-\mathrm{N}$ & - & - & 116 [104] & 70 [64] & $46[40]$ & $\begin{array}{c}118 \\
{[104]}\end{array}$ & 70 [64] & $46[40]$ \\
\hline \multirow[t]{2}{*}{ C. R\&D } & $\begin{array}{l}\mathrm{M}:+0.16 \\
\mathrm{Me}:+0.13 \\
\mathrm{~W}_{\mathrm{m}}:+0.05\end{array}$ & $\begin{array}{l}\text { M: } 2.55 \\
\text { Me: } 2.86 \\
W_{m}: 1.20\end{array}$ & $\begin{array}{c}0.25 \\
(3.34)^{*}\end{array}$ & $\begin{array}{c}0.18 \\
(2.83)^{*}\end{array}$ & $\begin{array}{c}0.33 \\
(2.12)^{*}\end{array}$ & $\begin{array}{c}-0.03 \\
(-1.02)\end{array}$ & $\begin{array}{c}-0.09 \\
(-3.35)^{*}\end{array}$ & $\begin{array}{c}0.03 \\
(1.27)\end{array}$ \\
\hline & $\mathrm{W}_{\mathrm{h}}:+0.16$ & $\mathrm{~W}_{\mathrm{h}}: 4.49$ & $\begin{array}{c}0.52 \\
(2.94)^{*}\end{array}$ & $\begin{array}{c}0.45 \\
(3.09)^{*}\end{array}$ & $\begin{array}{c}0.68 \\
(2.12)^{*}\end{array}$ & $\begin{array}{c}0.16 \\
(2.04)^{*}\end{array}$ & $\begin{array}{c}0.38 \\
(5.61)^{*}\end{array}$ & $\begin{array}{c}0.07 \\
(0.64)\end{array}$ \\
\hline - Adj. $R^{2}$ & - & - & $\begin{array}{c}0.11 \\
{[0.14]}\end{array}$ & $\begin{array}{c}0.23 \\
{[0.32]}\end{array}$ & $\begin{array}{c}0.09 \\
{[0.13]}\end{array}$ & $\begin{array}{c}0.02 \\
{[0.11]}\end{array}$ & $\begin{array}{c}0.47 \\
{[0.64]}\end{array}$ & $\begin{array}{c}0.02 \\
{[0.00]}\end{array}$ \\
\hline$-\mathrm{N}$ & - & - & 81 [69] & $35[29]$ & $46[40]$ & 81 [69] & 35 [29] & $46[40]$ \\
\hline $\begin{array}{l}\text { D. } \\
\text { Advertising }\end{array}$ & $\begin{array}{l}\text { M: }+0.23 \\
\text { Me: }+0.24 \\
W_{m}:+0.20\end{array}$ & $\begin{array}{l}\text { M: } 4.25 \\
\text { Me: } 3.42 \\
\mathrm{~W}_{\mathrm{m}}: 10.43\end{array}$ & $\begin{array}{c}0.15 \\
(1.07)\end{array}$ & $\begin{array}{c}0.18 \\
(1.08)\end{array}$ & $\begin{array}{c}-0.10 \\
(-0.37)\end{array}$ & $\begin{array}{c}0.22 \\
(2.08)^{*}\end{array}$ & $\begin{array}{c}0.22 \\
(1.97)^{*}\end{array}$ & $\begin{array}{c}0.13 \\
(1.30)\end{array}$ \\
\hline $\begin{array}{l}\text { - Adj. } \mathrm{R}^{2} \\
-\mathrm{N}\end{array}$ & $\begin{array}{l}- \\
-\end{array}$ & - & $\begin{array}{c}0.02 \\
94\end{array}$ & $\begin{array}{c}0.03 \\
63\end{array}$ & $\begin{array}{c}0.00 \\
31\end{array}$ & $\begin{array}{c}0.35 \\
94\end{array}$ & $\begin{array}{c}0.39 \\
63\end{array}$ & $\begin{array}{c}0.01 \\
31\end{array}$ \\
\hline
\end{tabular}

Notes: $\mathrm{M}=$ mean. $\mathrm{Me}=$ Median. $\mathrm{W}_{\mathrm{m}}=$ Sample size weighted mean. $\mathrm{W}_{\mathrm{h}}=$ weighted mean without Hirsch (1991). * denotes statistical significance at least at the $10 \%$ level. t-statistics reported in brackets using robust standard errors derived from applying the bootstrap. $\mathrm{N}$ is the number of estimates. The adjusted $\mathrm{R}$-squared and $\mathrm{N}$ figures reported in squared brackets relate to results without Hicks (1991). 
Table 5: Union and Market Power Interaction Effects and Union and Intangible and LongLived Assets Interaction Effects,

Meta-Significance and Precision Effect Tests, (Dependent Variable $=\ln \left|t_{i}\right|$ for MST and $t_{i}$ for FAT)

\begin{tabular}{|c|c|c|c|c|c|}
\hline $\begin{array}{c}\text { Market Power } \\
\text { Measure }\end{array}$ & $\begin{array}{c}\text { Coefficients on } \\
\text { lndf } \\
\text { All } \\
\text { Studies } \\
(1) \\
\end{array}$ & $\begin{array}{c}\text { Coefficients on } \\
\text { 1/SE } \\
\text { All } \\
\text { Studies } \\
(2) \\
\end{array}$ & $\begin{array}{c}\text { Asset } \\
\text { Measure }\end{array}$ & $\begin{array}{c}\begin{array}{c}\text { Coefficients } \\
\text { on lndf }\end{array} \\
\text { All } \\
\text { Studies } \\
(3)\end{array}$ & $\begin{array}{c}\text { Coefficients } \\
\text { on 1/SE } \\
\text { All } \\
\text { Studies } \\
(4) \\
\end{array}$ \\
\hline $\begin{array}{l}\text { Union* } \\
\text { Market } \\
\text { Power }\end{array}$ & $0.12(1.55)$ & $0.02(2.43)^{*}$ & $\begin{array}{l}\text { Union* } \\
\text { Tangible \& } \\
\text { Intangible } \\
\text { Assets }\end{array}$ & $0.23(1.63)$ & $-0.03(-1.78)^{*}$ \\
\hline $\begin{array}{l}\text { - Adj. } R^{2} \\
\text { - N }\end{array}$ & $\begin{array}{c}0.01 \\
87\end{array}$ & $\begin{array}{c}0.08 \\
87\end{array}$ & $\begin{array}{l}\text { - Adj. } R^{2} \\
\text { - } N\end{array}$ & $\begin{array}{c}0.13 \\
35\end{array}$ & $\begin{array}{c}0.08 \\
35\end{array}$ \\
\hline $\begin{array}{l}\text { Union* } \\
\text { Concentration } \\
\text { (Industry) } \\
\quad \text { - Adj. } \mathrm{R}^{2} \\
\text { - N }\end{array}$ & $0.16(1.63)$ & $0.02(2.11)^{*}$ & $\begin{array}{l}\text { Union* } \\
\text { Physical } \\
\text { Capital } \\
\text { - Adj. } \mathrm{R}^{2} \\
\text { - N }\end{array}$ & $0.03(0.25)$ & $-0.03(-0.02)$ \\
\hline $\begin{array}{l}\begin{array}{l}\text { Union* } \\
\text { Market Share } \\
\text { (Firm) } \\
\quad \text { - Adj. } \mathrm{R}^{2} \\
\text { - N }\end{array}\end{array}$ & $-0.04(-0.26)$ & $0.14(1.29)$ & $\begin{array}{l}\text { - Adj. } R^{2} \\
-\mathrm{N}\end{array}$ & $0.23(0.43)$ & $-0.04(-0.24)$ \\
\hline & & & $\begin{array}{l}\text { Union*RD\& } \\
\text { Advertising }\end{array}$ & $0.29(0.88)$ & $-0.05(-0.56)$ \\
\hline & & & $\begin{array}{l}\text { - Adj. } \mathrm{R}^{2} \\
-\mathrm{N}\end{array}$ & $\begin{array}{c}0.11 \\
23\end{array}$ & $\begin{array}{l}0.10 \\
23\end{array}$ \\
\hline
\end{tabular}

Notes: * denotes statistical significance at least at the $10 \%$ level. t-statistics reported in brackets using robust standard errors derived from applying the bootstrap. $\mathrm{N}$ is the number of estimates. 
Table 6: Meta-Regression Analysis, Union-Profit, Union-Market Power and Union-Capital Asset Interaction Profit Effects

(Dependent variable $=$ partial correlations)

\begin{tabular}{|c|c|c|c|c|}
\hline Variable & $\begin{array}{l}\text { All estimates } \\
\text { Fixed Effects } \\
\text { (1) }\end{array}$ & $\begin{array}{c}\text { All estimates } \\
\text { Random Effects } \\
\text { (2) }\end{array}$ & $\begin{array}{c}\text { Union*Market } \\
\text { Power Estimates } \\
\text { Fixed Effects } \\
\text { (3) }\end{array}$ & $\begin{array}{c}\text { Union*Capital } \\
\text { Assets Estimates } \\
\text { Fixed Effects } \\
\text { (4) }\end{array}$ \\
\hline Constant & $-0.09(-2.19)^{* *}$ & $-0.07(-1.89)^{*}$ & $-0.25(-0.70)$ & $-0.09(-1.94)^{*}$ \\
\hline US & $-0.07(-3.07)^{* * *}$ & $-0.04(-2.22)^{* *}$ & $0.14(1.46)$ & - \\
\hline Manufacturing & $-0.06(-3.80)^{* * *}$ & $-0.07(-4.91)^{* * *}$ & $-0.05(-0.51)$ & $0.04(1.41)$ \\
\hline Firm Level & $0.03(1.05)$ & $0.02(1.13)$ & $-0.01(-0.07)$ & - \\
\hline Density & $0.08(5.14)^{* * *}$ & $0.06(4.77)^{* * *}$ & $0.01(0.03)$ & $-0.28(-2.27)^{* *}$ \\
\hline Accounting & $0.02(1.61)$ & $0.02(1.47)$ & $0.07(1.87)^{*}$ & $0.03(1.30)$ \\
\hline Panel & $-0.01(-0.20)$ & $0.01(0.47)$ & $0.14(0.75)$ & - \\
\hline R\&D & $0.02(0.95)$ & $-0.01(-0.03)$ & $0.13(1.04)$ & - \\
\hline Advertising & $-0.06(-4.01)^{* * *}$ & $-0.06(-4.05)^{* * *}$ & $-0.20(-4.49)^{* * *}$ & - \\
\hline Capital & $0.07(4.49)^{* * *}$ & $0.06(5.09)^{* * *}$ & $-0.02(-0.20)$ & - \\
\hline Monopoly & $0.02(0.85)$ & $0.01(0.33)$ & - & $0.23(1.95)^{*}$ \\
\hline OLS & $-0.05(-2.82)^{* * *}$ & $-0.05(-3.24)^{* * *}$ & $0.11(1.75)^{*}$ & \\
\hline Adjusted $R^{2}$ & 0.19 & - & 0.32 & 0.14 \\
\hline $\begin{array}{l}\text { Standard Error Of } \\
\text { Regression }\end{array}$ & 0.13 & - & 0.12 & 0.10 \\
\hline$I^{2}$ & - & 0.81 & - & - \\
\hline$\tau^{2}$ & - & 0.0088 & - & - \\
\hline $\mathbf{N}$ & 532 & 532 & 87 & 35 \\
\hline
\end{tabular}

$*, * *, * *$ denotes statistical significance at the $10 \%, 5 \%$ and $1 \%$ levels, respectively. t-statistics reported in brackets using robust standard errors derived from applying the bootstrap. $\mathrm{N}$ is the number of estimates. $\mathrm{I}^{2}$ measures the degree of consistency (heterogeneity) between studies. $\tau^{2}$ measures between study variance. 


\section{ENDNOTES}

1 Throughout this paper we use the terms financial performance and profitability interchangeably.

${ }^{2}$ The effect of this selection process is to exclude studies conducted by: Tachibanaki and Noda (2000); Karier (1991); Bronars and Deere (1991); Bronars and Deere (1990); Frick and Sadowski 1995); Hirsch and Addison (1986); and Metcalf (2003), among others.

${ }^{3}$ The probit studies inform on the probability of unions impacting on financial performance. We are able to derive marginal effects for only a portion of these papers and, hence, are unable to combine these effectively with the other studies.

${ }^{4}$ This confidence interval is constructed using the bootstrap (Adams et al. 1997). A more conventional confidence interval ranges from -0.08 to -0.07 (see Hunter and Schmidt 2004).

${ }^{5}$ Card and Krueger (1995) and Stanley (2005) point out that statistical theory predicts that the t-ratio will be related to the square root of degrees of freedom, such that $E\left(\ln \left|t_{i}\right|\right)=\alpha_{0}+$ $\alpha_{l} \ln d f_{i}$. In a double log relationship with a genuine effect and no publication selectivity, $\alpha_{1}=1 / 2$.

${ }^{6}$ In unreported regressions we included dummy variables for other countries. These were not statistically significant. There are, unfortunately, few multiple studies for other countries. Specifically we have 9 studies for the United Kingdom, 4 for Germany, 2 each for Korea, Canada, Australia and Japan, and the rests are single country studies. The MST regression for just UK data is: $\ln \left|\mathrm{t}_{\mathrm{i}}\right|=-0.41(-0.77)+0.10 * \operatorname{lndf}_{\mathrm{i}}(1.26)$, with $\mathrm{n}=86$ and $\mathrm{t}$-statistics in brackets.

${ }^{7}$ This is confirmed also if only US data is. The MST regression for just US data is: $\ln \left|t_{i}\right|=-$ $2.02(-5.31)+0.43 * \operatorname{lndf}_{\mathrm{i}}(6.84)$, and the associated PET regression is: $\mathrm{t}_{\mathrm{i}}=-0.70(-3.98)-0.09 *$ 1/SE $\mathrm{SE}_{\mathrm{i}}(-7.03)$, with $\mathrm{n}=374$ and t-statistics in brackets. 
${ }^{8}$ Market based measures of profits are generally forward looking, while accounting based measures report what has happened in the past. Hence, market based measures are thought to reflect the market's valuation of the long run impact on profits, while accounting based measures reflect the past or the short run.

${ }^{9}$ Further sensitivity analysis involving studies other than Hirsch (1991) is available from the authors.

${ }^{10}$ The full MST results are available from the authors and are in accord with the PET results. The PET was run also by separating out the USA from the ROW but these results are not fundamentally different from those reported in the text where all regions are combined together.

${ }^{11}$ Stanley (2005) and (2007) shows that PET is a more powerful and reliable test than is the MST.

${ }^{12}$ In most cases there are too few estimates for separate analyses by profit measure.

13. In effect, this means that there is not a single union-profit effect that all studies are estimating. Rather, there is a distribution of such effects.

14 The constant is negative and hence the positive coefficient on Density implies lower negative union-profit effects.

15 Theory is ambivalent about the impact of unions on capital. In their meta-analysis of the impact of unions on capital, Doucouliagos and Laroche (2003c) found that unions have a negative effect on capital investment.

${ }^{16}$ Note that estimating equation 6 means excluding $\mathrm{K}$ and hence resulting in a possible misspecification. 